Bangladesh J. Bot. 48(1): 123-127, 2019 (March)

\title{
IMPACT OF FOLIAR NUTRIENT SPRAYS, CROP AND SPATIAL MANIPULATION ON SEED YIELD OF CALLISTEPHUS CHINENSIS (L.) NEES
}

\author{
Muneeb Ahmad Wani*, Ambreena Din, FU Khan, Raiz Ahmed Lone, \\ Gazanfer Gani, Shameen IQbal and ImtiYaz Tahir Nazki \\ Division of Floriculture and Landscape Architecture, Faculty of Horticulture, SKUAST-K, \\ Shalimar, Srinagar 190001, Jammu and Kashmir
}

Keywords: Callistephus, Seed moisture content, Seed yield, Sprays, Test weight

\begin{abstract}
An attempt was made to study the effect of pinching, plant densities and foliar nutrient sprays on seed yield and quality parameters in China aster cv. Powder puff. The experiment comprised of two levels of pinching $\left(\mathrm{P}_{0}=\right.$ No pinching, $\mathrm{P}_{1}=$ Pinching $)$, three planting densities $\left(\mathrm{D}_{1}=30\right.$ plants $\mathrm{m}^{-2}, \mathrm{D}_{2}=36$ plants $\mathrm{m}^{-2}$ and $D_{3}=42$ plants $\left.\mathrm{m}^{-2}\right)$ and three levels of commercial nutrient sprays $\left(S_{1}=3\right.$ sprays, $S_{2}=4$ sprays and $S_{3}=5$ sprays), constituting a total of 18 treatment combinations replicated thrice in randomized complete block design (RCBD). Pinching at visible bud stage, significantly increased 1000 seed weight $(2.18 \mathrm{~g})$ and seed yield (490.85 kg/ha), Increasing the planting density resulted in increased seed yield (485.55 kg/ha) and 1000 seed weight $(2.05 \mathrm{~g})$. On the other hand, 4 and 5 nutrient sprays significantly improved seed yield (463.12 $\left.\mathrm{kg} / \mathrm{ha}^{-}\right)$and 1000 seed weight $(1.95 \mathrm{~g})$. The results from the study suggest that increased branching with apical bud removal, wider planting space and 4 to 5 foliar applications of multi-nutrient sprays, significantly improves seed yield and quality attributes of transplanted China aster. While suggesting the best combination of pinching, spacing and nutrient sprays, the economics of flower production was duly considered.
\end{abstract}

\section{Introduction}

Floriculture as a branch of horticulture relates to cultivation of flowering and ornamental plants for gardens and floristry. It includes cut flowers, cut greens, bedding plants, indoor plants and potted plants etc. Floriculture has become a fast-growing industry because of urbanization and rising living standards of the people paving way to inclined demands of flowers and flower products, thus making floriculture as one of the most important commercial trades in agriculture (Wani et al. 2018). Among various flowering annuals, China aster is having an important position in Indian floriculture industry. In fact, it has widely replaced an already grown annual Chrysanthemum up to greater extent in Indian floriculture industry. There has always been a limitation of availability of quality seed supply in annuals particularly in Indian markets and the quest for quantum production of quality seed seems as a never-ending endeavour. Seed production of annuals is an important aspect of commercial floriculture. Owing to ever increasing demand for quality seeds of China aster throughout India, there is a need to increase the seed production per unit area in the crop which would ensure good returns for growers also. The cultivar Powder puff of China aster has been emerged as an important cultivar among Indian floriculture growers owing to its versatility. Though the production of seed is a genetically determined trait, but it is also largely affected with many specific and timely cultural interventions like foliar spray of nutrients, planting space, pinching etc. China aster plant has a cymose inflorescence and final yield would depend upon number of flowers/plant. Therefore, there is a need to develop interventions to increase flower number/plant, which in turn depends upon number of secondary and tertiary branches. Pinching first bloom early in plants with cymose inflorescence usually increases number

*Author for correspondence: <wanimuneeb05@gmail.com>, <wanimuneeb@ skuastkashmir.ac.in>. 
of flowers/plant (Gnyandev et al. 2014). Hence annual flower seed producers need field-tested recommendations on pinching practices in such crops.

Plant population per unit area has a significant bearing on final seed yield in flowering annuals. Many studies have been conducted to determine the optimum plant density for China aster, however, there is no single recommendation regarding manipulation of plant architecture, plant population per unit area and sustained micronutrient feeding. The practice of spacing varies with the habit of the cultivars and the agro-climatic regions. High plant density brings out various modifications in the growth of plants. Kashmir valley which is situated at an altitude of 1620 masl is a region of high incident radiation that allows scope for accommodating more plants per unit area, particularly during summer months. Though quality of seeds is primarily a varietal trait, it is also greatly influenced by climatic, geographical, nutritional and plant density factors. Amongst them, climatic and geographic factors of Kashmir valley are most congenial for optimum and quality seed production for flowering annuals. There is a vast scope of growing China aster in J \& $\mathrm{K}$ throughout the year as both cut and loose flower.

In recent years, uses of micronutrients have been considered to be essential for higher yields and quality production. The micronutrients owing to their metabolic function in the plant system are involved in the synthesis of tryptophan as the precursor for auxin which promotes production of foliage and flowers (Chen et al. 1982). Plants grown on micronutrient deficient soil can exhibit a reduction in plant growth and yield as major nutrients.

Thus keeping in view the above considerations, the present investigation was undertaken to evaluate the response of seed production to varying planting density and pinching and nutrient sprays.

\section{Materials and Methods}

The present investigation was conducted at Division of Floriculture and Landscape Architecture, Faculty of Horticulture, SKUAST-Kashmir, Shalimar, Srinagar, J and K during the year 2016 and 2017. China aster (Callistephus chinensis) was used as test material.

Moisture content of seeds (w) with 3 replicates each having $1 \mathrm{~g}$ seed was evaluated by drying at $120^{\circ} \mathrm{C}$ for $1 \mathrm{hr}$. After that the moisture content was calculated with the following formula:

$$
w=\frac{(a-b)}{(a-c)} \quad 100
$$

where $\mathrm{w}=$ seed moisture content in per cent, $\mathrm{a}=$ weight of container with seeds before drying, $b=$ weight of container with seeds after drying, $c=$ weight of container.

One thousand seeds were manually counted from seeds of five plants in each treatment and 1000-seed weight was recorded by adopting ISTA procedure (Anonymous. 1996) and expressed in grams.

For the purpose of determination of seed yield/plant, five pre-tagged plants were harvested separately and seeds were separated, cleaned, weighed and average seed yield/plant was estimated and expressed in grams. The seed yield/hectare was computed based on the seed yield/plant and expressed in kilograms.

The experiment was undertaken with 18 treatment combinations, comprising of 2 levels of pinching $\left[\mathrm{P}_{0}=\right.$ no pinching and $\mathrm{P}_{1}=$ pinching $], 3$ levels of planting densities $\left[\mathrm{D}_{1}=30\right.$ plants $\mathrm{m}^{-2}$, $\mathrm{D}_{2}=36$ plants $\mathrm{m}^{-2}$ and $\mathrm{D}_{3}=42$ plants $\left.\mathrm{m}^{-2}\right]$ and 3 levels of nutrient sprays $\left[\mathrm{S}_{1}=3\right.$ sprays, $\mathrm{S}_{2}=4$ sprays and $S_{3}=5$ sprays] and replicated thrice. Total numbers of plots were fifty four. Data analyses were carried out using SPSS software with analysis of variance. Means were compared at $\mathrm{p} \leq 0.05$ level of significance. 


\section{Results and Discussion}

Pinching improved 1000-seed weight to $2.18 \mathrm{~g}$ in comparison to $1.60 \mathrm{~g}$ recorded in unpinched plants (Table 1). China aster head has a compound inflorescence where individual florets with fertilised ovules represent one seed. In large blooms, photosynthates are partitioned between larger numbers of fertilised ovules, thus resulting in seeds with less 1000-seed weight. Since pinching results in smaller bloom, therefore weight of individual seeds is improved in comparison to flowers borne on un-pinched plants. In any crop, seed yield is a function of plant growth, number of productive branches, number of flowers/plant, number of seeds/flower, test weight, number of flowers/plot etc. Arresting of vertical growth of plants by pinching apical bud always results in production of more number of productive branches. In the present study, pinched plants $\left(\mathrm{P}_{1}\right)$ recorded significantly highest seed yield/ha $(490.85 \mathrm{~kg})$ as compared to no pinching $(425.73$ $\mathrm{kg}$ ). The increase in seed yield and yield attributing parameters noticed with pinching was mainly due to production of more number of productive branches and more number of leaves (Table 2). Pinching results in efficient production and distribution of photoassimilates and hence improved seed weight. Similar beneficial effects of pinching on seed yield and yield parameters are reported by Grawal et al. (2004) and Singh and Baboo (2003) in chrysanthemum.

Table 1. Effect of pinching, planting density and nutrient sprays on 1000- seed weight (g) of Callistephus chinensis (L.) Nees cv. 'Powder Puff'.

\begin{tabular}{|c|c|c|c|c|c|c|c|c|c|c|}
\hline & \multicolumn{4}{|c|}{$\mathrm{P}_{0}$} & \multicolumn{4}{|c|}{$\mathrm{P}_{1}$} & \multirow{2}{*}{$\begin{array}{l}\text { Factor } \\
\text { Spray }\end{array}$} & \multirow{2}{*}{$\begin{array}{l}\text { Mean } \\
\text { Density }\end{array}$} \\
\hline & $\mathrm{D}_{1}$ & $\mathrm{D}_{2}$ & $\mathrm{D}_{3}$ & $\begin{array}{l}\text { Sub } \\
\text { Mean }\end{array}$ & $\mathrm{D}_{1}$ & $\mathrm{D}_{2}$ & $\mathrm{D}_{3}$ & $\begin{array}{l}\text { Sub } \\
\text { mean }\end{array}$ & & \\
\hline $\mathrm{S}_{1}$ & 1.65 & 1.56 & 1.31 & 1.51 & 2.27 & 2.18 & 1.86 & 2.10 & 1.80 & 2.05 \\
\hline $\mathrm{S}_{2}$ & 1.75 & 1.59 & 1.48 & 1.61 & 2.35 & 2.17 & 2.12 & 2.21 & 1.91 & 1.90 \\
\hline $\mathrm{S}_{3}$ & 1.86 & 1.68 & 1.50 & 1.68 & 2.42 & 2.19 & 2.08 & 2.23 & 1.95 & 1.72 \\
\hline Mean & 1.75 & 1.61 & 1.43 & 1.60 & 2.35 & 2.18 & 2.02 & 2.18 & & \\
\hline & Pinching & 0.014 & & $P \times D$ & & NS & & & & \\
\hline \multirow[t]{3}{*}{$(\mathrm{p} \leq 0.05)$} & Density & 0.018 & & $P \times S$ & & 0.025 & & & & \\
\hline & Spray & 0.018 & & $\mathrm{D} \times \mathrm{S}$ & & 0.031 & & & & \\
\hline & & & & $\mathrm{P} \times \mathrm{D} \times \mathrm{S}$ & & 0.043 & & & & \\
\hline $\begin{array}{l}\mathrm{P}_{0}=\text { No pir } \\
\mathrm{D}_{1}=30 \mathrm{pl}\end{array}$ & $\begin{array}{l}\text { ing } \\
\mathrm{s} \mathrm{m}^{-2}\end{array}$ & & $42 \mathrm{p}$ & $\begin{array}{l}\text { nts } \mathrm{m}^{-2} \\
\text { nts } \mathrm{m}^{-2}\end{array}$ & $\begin{array}{l}\mathrm{P}_{1}= \\
\mathrm{S}_{1}=\end{array}$ & $\begin{array}{l}\text { ching } \\
\text { prays }\end{array}$ & & $\begin{array}{l}S_{2}=4 \\
S_{3}=5\end{array}$ & & \\
\hline
\end{tabular}

Present study shows increased 1000 -seed weight under wider spacing which might be due to more efficient photosynthesis. However, seed yield/ha $(485.55 \mathrm{~kg})$ was significantly higher under closer spacing in comparison to $436.15 \mathrm{~kg}$ under wider $\left(30 \mathrm{plants}^{-2}\right)$ spacing. The study indicates that benefits assured to total seed yield as a result of closer spacing for out weigh advantages in terms of increased 1000-seed weight as a result of wider spacing. These facts are in line with those of Shivakumar (2000) in marigold and Ramesh Kumar et al. (2003) and Pandey et al. (2017) in China aster. Higher seed yield in denser planting could be attributed to more number of plants per unit area as against to less number of plants per unit area under wider spacing. Shah et al. (2005) in China aster and Chauhan et al. (2005) in marigold reported similar findings.

Extending nutrient sprays deep into crop cycle resulted in improved 1000- seed weight and seed yield $(\mathrm{kg} / \mathrm{h})$. Most of the filling of seeds takes place towards the end of crop cycle. This indicated the importance of continued supply of nutrients towards improving seed plumpness and total seed yield. Numerous studies like that of Deshmukh and Wavhal (1998 and 1999) in China aster, Barman and Pal (1999) in Chrysanthemum and Kumar et al. (2003) in carnation reported improved 1000-seed weight and seed yield with the application of foliar nutrients. 
In the present study, $2^{\text {nd }}$ and $3^{\text {rd }}$ order interactions towards improving 1000 -seed weight and seed yield were significant. This demonstrates the additive effect of pinching, spacing and increased frequency of sprays towards realizing higher net returns per unit area.

No significant effect of pinching, planting density and nutrient sprays on seed moisture content was observed (Table 3). This shows that improvements in 1000-seed weight and seed yield $(\mathrm{kg} / \mathrm{ha})$ under variable pinching, planting density and nutrient spray frequency were not due to differences in seed moisture content.

Table 2. Effect of pinching, planting density and nutrient sprays on seed yield $\mathrm{kg} / \mathrm{ha}$ of Callistephus chinensis (L.) Nees cv. 'Powder Puff'.

\begin{tabular}{|c|c|c|c|c|c|c|c|c|c|c|}
\hline & \multicolumn{4}{|c|}{$\mathrm{P}_{0}$} & \multicolumn{4}{|c|}{$\mathrm{P}_{1}$} & \multicolumn{2}{|c|}{ Factor mean } \\
\hline & $\mathrm{D}_{1}$ & $\mathrm{D}_{2}$ & $\mathrm{D}_{3}$ & $\begin{array}{c}\text { Sub } \\
\text { mean }\end{array}$ & $\mathrm{D}_{1}$ & $\mathrm{D}_{2}$ & $\mathrm{D}_{3}$ & $\begin{array}{c}\text { Sub } \\
\text { mean }\end{array}$ & Spray & Density \\
\hline $\mathrm{S}_{1}$ & 409.45 & 417.58 & 438.49 & 421.84 & 452.71 & 481.41 & 516.60 & 483.57 & 452.71 & 436.15 \\
\hline $\mathrm{S}_{2}$ & 413.21 & 419.53 & 447.06 & 426.60 & 460.78 & 486.41 & 527.29 & 491.49 & 459.05 & 453.18 \\
\hline $\mathrm{S}_{3}$ & 415.73 & 419.87 & 450.63 & 428.74 & 465.01 & 494.27 & 533.22 & 497.50 & 463.12 & 485.55 \\
\hline Mean & 412.80 & 418.99 & 445.39 & 425.73 & 459.50 & 487.36 & 525.70 & 490.85 & & \\
\hline \multirow{4}{*}{\multicolumn{2}{|c|}{$\mathrm{CD}(\mathrm{p} \leq 0.05)$}} & Pinching & \multicolumn{2}{|c|}{0.684} & \multicolumn{2}{|c|}{$P \times D$} & 1.184 & & & \\
\hline & & Density & \multicolumn{2}{|c|}{0.837} & \multicolumn{2}{|c|}{$\mathrm{P} \times \mathrm{S}$} & 1.184 & & & \\
\hline & & Spray & \multirow{2}{*}{\multicolumn{2}{|c|}{0.837}} & \multicolumn{2}{|c|}{$\mathrm{D} \times \mathrm{S}$} & 1.450 & & & \\
\hline & & & & & \multicolumn{2}{|c|}{$\mathrm{P} \times \mathrm{D} \times \mathrm{S}$} & 2.051 & & & \\
\hline \multirow{2}{*}{\multicolumn{3}{|c|}{$\begin{array}{l}\mathrm{P}_{0}=\text { No pinching } \\
\mathrm{D}_{1}=30 \text { Plants } \mathrm{m}^{-2}\end{array}$}} & \multirow{2}{*}{\multicolumn{2}{|c|}{$\begin{array}{l}\mathrm{D}_{2}=36 \text { plants } \mathrm{m}^{-2} \\
\mathrm{D}_{3}=42 \text { plants } \mathrm{m}^{-2}\end{array}$}} & \multirow{2}{*}{\multicolumn{2}{|c|}{$\begin{array}{l}\mathrm{P}_{1}=\text { pinching } \\
\mathrm{S}_{1}=3 \text { sprays }\end{array}$}} & \multirow{2}{*}{\multicolumn{2}{|c|}{$\begin{array}{l}S_{2}=4 \text { sprays } \\
S_{3}=5 \text { sprays }\end{array}$}} & & \\
\hline & & & & & & & & & & \\
\hline
\end{tabular}

Table 3. Effect of pinching, planting density and nutrient sprays on seed moisture content (\%) of Callistephus chinensis (L.) Nees cv. 'Powder Puff'.

\begin{tabular}{|c|c|c|c|c|c|c|c|c|c|c|}
\hline & \multicolumn{4}{|c|}{$\mathrm{P}_{0}$} & \multicolumn{4}{|c|}{$\mathrm{P}_{1}$} & \multicolumn{2}{|c|}{ Factor mean } \\
\hline & $\mathrm{D}_{1}$ & $\mathrm{D}_{2}$ & $\mathrm{D}_{3}$ & $\begin{array}{c}\text { Sub } \\
\text { mean }\end{array}$ & $\overline{D_{1}}$ & $\mathrm{D}_{2}$ & $\mathrm{D}_{3}$ & $\begin{array}{c}\text { Sub } \\
\text { mean }\end{array}$ & Spray & Density \\
\hline $\mathrm{S}_{1}$ & 8.67 & 7.45 & 8.50 & 8.21 & 9.09 & 7.76 & 8.15 & 8.33 & 8.27 & 8.01 \\
\hline $\mathrm{S}_{2}$ & 6.53 & 8.87 & 7.77 & 7.72 & 8.09 & 7.89 & 9.28 & 8.42 & 8.07 & 7.87 \\
\hline $\mathrm{S}_{3}$ & 7.38 & 7.39 & 8.52 & 7.76 & 8.29 & 7.88 & 7.91 & 8.03 & 7.90 & 8.36 \\
\hline Mean & 7.53 & 7.90 & 8.27 & 7.90 & 8.49 & 7.84 & 8.44 & 8.26 & & \\
\hline \multirow[t]{4}{*}{$\mathrm{CD}(\mathrm{p} \leq 0.05)$} & \multicolumn{2}{|c|}{$\mathrm{P}$} & NS & \multicolumn{2}{|c|}{$P \times D$} & NS & & & & \\
\hline & \multicolumn{2}{|c|}{ D } & NS & \multicolumn{2}{|c|}{$\mathrm{P} \times \mathrm{S}$} & NS & & & & \\
\hline & \multicolumn{2}{|c|}{$\mathrm{D}$} & NS & \multicolumn{2}{|c|}{$\mathrm{D} \times \mathrm{S}$} & NS & & & & \\
\hline & & & & \multicolumn{2}{|c|}{$\mathrm{P} \times \mathrm{D} \times \mathrm{S}$} & NS & & & & \\
\hline $\begin{array}{l}\mathrm{P}_{0}=\text { No pinchi } \\
\mathrm{D}_{1}=30 \text { Plants }\end{array}$ & & & $\begin{array}{l}=36 \mathrm{p} \\
=42 \mathrm{p}\end{array}$ & $\begin{array}{l}\text { nts } \mathrm{m}^{-2} \\
\text { nts } \mathrm{m}^{-2}\end{array}$ & $\begin{array}{l}\mathrm{P}_{1}= \\
\mathrm{S}_{1}=\end{array}$ & $\begin{array}{l}\text { pinchi } \\
3 \text { spra }\end{array}$ & & $\begin{array}{l}\mathrm{S}_{2}= \\
\mathrm{S}_{3}=\end{array}$ & $\begin{array}{l}\text { sprays } \\
\text { sprays }\end{array}$ & \\
\hline
\end{tabular}

The results from the study suggest that increased branching with terminal bud removal, wider planting space and 4 to 5 foliar applications of multi-nutrient sprays, significantly improved seed yield and quality attributes of transplanted China aster. The economical aspect of the research was also given a due consideration.

\section{Acknowledgements}

The authors like to express sincere gratitude to University Grants Commission, Government of India for providing the financial support in the form of "Maulana Azad National Fellowship". 


\section{References}

Anonymous 1996. International Rules for Seed Testing. Seed Science and Technology 24 (Suppl.): 1-335

Barman D and Pal P 1999. Effect of micronutrient on growth and flowering of Chrysanthemum morifolium cv. 'Chandrama'. Haryana Journal of Horticulture Sciences 28(1-2): 78-79.

Chauhan S, Singh CN and Singh AK 2005. Effect of vermicompost and pinching on growth and flowering in marigold cv PusaNarangiGainda. Progressive Horticulture 37(2): 419-22.

Chen Y, Skinitz B, Cohen A and Elber Y 1982. The effect of various iron-containing fertilizers on growth and propagation of Gladiolus grandiflorus. Scientia Horticulturae 18(2): 169-175.

Deshmukh MR and Wavhal KN 1998. Effect of iron on growth and flowering of aster. J. Maharashtra Agric. Univ. 23(2): 99-101.

Deshmukh MR and Wavhal KN 1999. Effect of zincon growth and flowering of aster. J. Maharashtra Agric. Univ. 24(2): 224-226.

Gnyandev B, Kurdikeri MB, Patil AA and Channappagoudar BB 2014. Effect of pinching, fertilizer levels, and growth retardants sprays on seed yield and quality in China aster cv. 'Phule Ganesh'. International Journal of Tropical Agriculture 32: 3-4

Grawal HS, Ramesh K and Singh H2004. Effect of nitrogen, planting time and pinching on flower production in chrysanthemum cv. Flirt. Journal of Ornamental Horticulture 7(2): 196-199.

Irwin D and Aarssen WL 1996. Testing for cost of apical dominance in vegetation: a field study of three species. Annales Botanici Fennici 33: 123-128.

Koostra PT and Harrington JF 1969. Biochemical effects of age on membranal lipids of Cucumis sativus L. Seed Proceedings International Seed Testing Association 34: 329.

Kumar H, Singh S, Ahlawat VP and Yadav BS 2003.Influence of nitrogen and zinc application on growth, flowering and chlorophyll content of tuberose (Polianthus tuberosa Linn.) cv. 'Double'. Haryana J. Hort. Sci. 32(3/4): 212-215.

Mohammadi G, Khah EM, Petropoulos SA and Chachalis DB 2016. Effect of foliar application of micronutrients on plant growth and seed germination of four okra cultivars. Not. Bot. Horti. Agrobo. 44(1): 257-263

Pandey V, Pandey N and Rao VK 2017. Impact of planting geometry on seed quality of china aster genotypes under mid hill conditions of Uttarakhand. Chemical Science Review and Letters 6(23): 1791-1794

Ramesh Kumar, Singh K, Kumar R and Singh K 2003. Effect of growth regulator and shoot tip pinching on carnation. Journal of Ornamental Horticulture 6(2): 134-136.

Sajjan AS, Shekhargouda M and Badanur VP 2002. Influence of apical pinching and fruit picking on growth and seed yield of okra. Karnataka Journal of Agricultural Sciences 15(2): 367-372.

Shah UA, Khan FU, Lone RA, Nanda AB and Beigh MA 2005. Effect of nitrogen and spacing on growth and flowering in China aster. Progressive Horticulture 37(2): 453-455.

Shivakumar CM 2000. Effect of mother plant nutrition, plant density and maturity on seed yield and quality in marigold. M.Sc. (Agri). Thesis, University of Agricultural Sciences Dharwad.

Singh MK and Baboo R 2003. Response of nitrogen, potassium and pinching levels on growth and flowering in chrysanthemum. Journal of Ornamental Horticulture 6(4): 390-393.

Wani MA, Nazki IT, Din A, Iqbal S, Wani, SA, Khan FU and Neelofar (Eds) 2018. Floriculture Sustainability Initiative: The Dawn of New Era. In: Lichtfouse E. Sustainable Agriculture Reviews 27. Sustainable Agriculture Reviews, vol 27. Springer, Cham., 92 pp. 